\title{
Rice Tolerance to Saflufenacil in Clomazone Weed Control Program
}

\author{
E. R. Camargo, ${ }^{1,2}$ S. A. Senseman, ${ }^{1}$ G. N. McCauley, ${ }^{3}$ and J. B. Guice ${ }^{4}$ \\ ${ }^{1}$ Department of Soil and Crop Sciences, Texas A\&M University, College Station, TX 77843-2474, USA \\ ${ }^{2}$ Conselho Nacional do Desenvolvimento Científico e Tecnológico (CNPq), 70750-901 Brasília, DF, Brazil \\ ${ }^{3}$ Texas AgriLife Research, David Wintermann Rice Research Center, Eagle Lake, TX 77434, USA \\ ${ }^{4}$ BASF Corporation, Agricultural Products Division, 6583 Main Street, Winnsboro, LA 71295, USA \\ Correspondence should be addressed to E. R. Camargo, edinalvo_camargo@yahoo.com.br
}

Received 22 July 2011; Accepted 20 September 2011

Academic Editor: Patrick J. Tranel

Copyright (๑) 2011 E. R. Camargo et al. This is an open access article distributed under the Creative Commons Attribution License, which permits unrestricted use, distribution, and reproduction in any medium, provided the original work is properly cited.

This research was conducted to evaluate (1) rice tolerance to saflufenacil applied preemergence (PRE) and postemergence (POST) and (2) the combination of saflufenacil and clomazone in light-textured soils. No injury from PRE application of saflufenacil was observed in 2009, and minimal injury for saflufenacil alone was observed in 2010. Injury as high as $68 \%$ was observed with combinations of $505 \mathrm{~g} \mathrm{ha}^{-1}$ of clomazone applied PRE and $50 \mathrm{~g} \mathrm{ha}^{-1}$ of saflufenacil applied POST in 2009 early evaluations. No interaction between clomazone and POST saflufenacil rates was observed in 2010. Rice injury intensified with increasing rates of saflufenacil applied POST. However, rice recovered with time for herbicide treatments applied PRE and POST in both years. Consequently, rice yield was not affected by any of the saflufenacil rates applied either PRE or POST in a clomazone weed control program.

\section{Introduction}

Rice is a staple food in numerous countries around the world. Rice consumption provides more calories than any other single food [1], serving daily as a source of carbohydrate, proteins, lipids, vitamins, and minerals [2,3]. Rice yield is on an upward path to achieve higher worldwide production as indicated by data compiled in the last ten years by the Food and Agriculture Organization (FAO). Production increased from 599 million tons in 2000 to 685 million tons in 2009 [4]. However, current supply trends are considered insufficient to track projected demand as the world population continues to rise [5]. Crop management will be even more important in production areas in order to maintain and/or expand rice production.

In the United States, 1.07 million hectares were harvested resulting in the production of 8.5 million tons of rice in the crop season of 2011 [6]. The southern states of Arkansas, California, Louisiana, Mississippi, Texas, and Missouri primarily contributed to this production. As weeds are one of the most important biological factors limiting rice production [7], weed management is crucial to maximize rice yield potential. Several annual grasses and broadleaf species are considered troublesome weeds in United States rice regions [8]. In Arkansas, the largest-producing state, barnyardgrass (Echinochloa crus-galli) was reported to be the most problematic grassy weed [9]. In the same survey, clomazone was described to be the most regularly recommended preemergence (PRE) herbicide. Clomazone is a relatively recent herbicide in rice, with commercialization occurring at the beginning of the century $[10,11]$. This herbicide is metabolized to the 5-keto form of clomazone. The 5keto form, which is the active herbicide, inhibits 1-deoxy-Dxylulose 5-phosphate synthase, a key component to plastid isoprenoid synthesis [12]. Symptomology of clomazone includes bleaching that can progress to necrosis $[12,13]$.

Weed management programs with clomazone are widely utilized because of the low-cost and effective annual grass control [14]. Problematic species such as barnyardgrass and broadleaf signalgrass (Urochloa platyphylla) can be effectively controlled by clomazone $[14,15]$. Also, occurrence of barnyardgrass resistant to propanil and quinclorac $[11,16,17]$ 
has contributed to considerable use of clomazone for weed management in rice. Although clomazone provides excellent control of grasses with the recommended rates for rice, it is weak on broadleaf and sedge species [11].

Saflufenacil is a new herbicide currently registered for burndown and PRE applications in winter cereals, soybean, corn, and other crops [18-20]. This herbicide is highly effective on dicotyledon weeds with both residual and contact activity [21,22]. Consequently, saflufenacil could broaden the weed control spectrum in a clomazone program by providing broadleaf control. Improvement in broadleaf weed control was indicated as a priority topic of research by survey conducted in Arkansas [9]. Development of saflufenacil for rice could generate a new tool to help farmers with some of the specific broadleaf weed control problems. However, crop tolerance and herbicide interactions need to be evaluated before saflufenacil can be used for weed control in rice.

Saflufenacil is a member of the pyrimidinedione chemical class of herbicides, which inhibit the protoporphyrinogen IX oxidase (PPO) enzyme [23]. Crop response to saflufenacil has been studied for PRE applications in proso millet [24] and leguminous crops [20], for postemergence (POST) applications in winter wheat $[25,26]$, and for PRE and POST applications in corn [19], wheat, barley, and oats [18, 27] but currently no work has been published regarding rice tolerance to this herbicide. Saflufenacil can provide broadleaf weed control when applied PRE or POST as Geier et al. [21] determined in a greenhouse study with five weed species. Although control can be achieved with PRE and POST applications, crop injury may be a limiting factor to use saflufenacil in a weed control program with clomazone.

PRE tank-mixed application may cause higher rice injury especially in light-textured soils. Saflufenacil has been demonstrated to be safe in PRE applications for several grass crops such as corn, wheat, barley and oats $[18,19,27]$, however, rice response has not been investigated in lighttextured soils. The clomazone label excluded its applications in coarse soils, but results obtained by Willingham et al. [14] indicated that it could be used without causing significant injury. Therefore, crop response to combinations of clomazone and saflufenacil in light-textured soils could indicate potential for use of these herbicides in a rice weed control program.

POST application of saflufenacil is not currently recommended for in-crop weed control. Unacceptable injury and yield reduction in barley, oats, and wheat were observed for POST applications of this material [18]. In corn, application of saflufenacil without adjuvant at spike (coleoptile has reached the soil surface) and 2- to 3-leaf stages resulted in acceptable tolerance; however, when adjuvant was included with the herbicide, crop injury increased resulting in yield loss [19]. Moreover, recent results in winter wheat indicated saflufenacil potential for POST applications when used in combination with 2,4-D amine without nonionic surfactant $[25,26]$. Also, a water-dispersible granule formulation provided minimal injury in POST applications [26].

Hence, experimentation with applications of saflufenacil is needed to evaluate the rice response to PRE and POST treatments. Depending on crop tolerance, saflufenacil used in combination with clomazone could result in an alternative tool for rice farmers providing a comprehensive weed control program. Therefore, the objective of this research was to evaluate (1) rice tolerance to saflufenacil applied alone PRE and POST and (2) the combination of saflufenacil and clomazone in light-textured soils.

\section{Material and Methods}

Two separate experiments (PRE and POST saflufenacil) were conducted during 2009 and 2010 at the Texas A\&M AgriLife Research and Extension Center located at Eagle Lake, TX. The soil was a Nada fine sandy loam (fine-loamy, siliceous, active, hyperthermic Albaquic Hapludalfs) with $56.8 \%$ of sand, $33.6 \%$ of silt, $9.6 \%$ of clay, $0.8 \%$ of organic carbon, and $\mathrm{pH}$ of 6.5. The area used to conduct the research was in a rice-fallow rotation where rice was seeded every three years. Therefore, studies were conducted in different fields within the research station each year. Soil was disked to reduce vegetative biomass during the summer preceding establishment of experiments. Prior to crop seeding in the spring, the seedbed was cultivated again and the soil surface was graded to guarantee adequate field slope.

The experiments were drill-seeded on April 15th, 2009, and March 31st, 2010 using the cultivar "Cocodrie" at the rate of $80 \mathrm{~kg} \mathrm{ha}^{-1}$. Emergence of rice occurred 11 days after seeding (DAS) the experiments in 2009 and 8 DAS in 2010. In both years, plots were formed by seven rows spaced at $19 \mathrm{~cm}$ from each other ( $1.3 \mathrm{~m}$ wide) and measuring $4.9 \mathrm{~m}$ long. Plots were separate from each other by a $0.3-\mathrm{m}$ alley. Before establishing season-long flood, rice fields were submerged and subsequently drained at least twice to introduce moisture in the soil. Season-long flood was initiated 25 days after rice emergence (DAE) in 2009 and 35 DAE in 2010. Triple superphosphate, potassium chloride, and urea were applied and incorporated in the soil prior to seeding at a rate of $53 \mathrm{~kg} \mathrm{ha}^{-1}$ of $\mathrm{P}_{2} \mathrm{O}_{5}, \mathrm{~K}_{2} \mathrm{O}$, and $\mathrm{N}$, respectively. Midseason nitrogen fertilization was conducted at preflooding using $79 \mathrm{~kg} \mathrm{ha}^{-1}$ of nitrogen in the form of urea followed by $89 \mathrm{~kg} \mathrm{ha}^{-1}$ at panicle differentiation in the form of ammonium sulfate.

The experimental design was a randomized complete block with a factorial arrangement. The treatments included combinations of three rates of clomazone $(0,392$, and $505 \mathrm{~g} \mathrm{ha}^{-1}$, Command $3 \mathrm{ME}$, microencapsulated formulation, FMC Corporation, 1735 Market Street, Philadelphia, $\mathrm{Pa}$ 19103) and five rates of saflufenacil (Sharpen, suspension concentrate formulation, BASF Corporation, 26 Davis Drive, Research Triangle Park, NC 27709-3528). In the experiment with PRE applications of saflufenacil, rates were 0, 25, 50, 100, and $200 \mathrm{gha}^{-1}$. Rates for POST applications of saflufenacil were $0,12.5,18.75,25$, and $50 \mathrm{~g} \mathrm{ha}^{-1}$. Treatments were replicated four times. Clomazone treatments were applied immediately after rice seeding in both experiments. Clomazone and saflufenacil rates were tank-mixed in the experiment with PRE applications. In the study with POST applications of saflufenacil, treatments were applied at the 4- to 6-leaf stage (V4-V6, according to Counce et al. [28]). Methylated seed oil (Methylated spray oil, blend of distilled 
methyl esters and nonionic surfactants, Helena Chemical Company, 225 Schilling Blvd., Suite 300, Collierville, TN 38017 ) at $1 \% \mathrm{v} / \mathrm{v}$ was included in POST applications.

Clomazone treatments provided effective control of grassy weeds. Consequently, treatments that did not receive clomazone application were maintained grass-free by applying propanil plus quinclorac. In 2009, propanil (4485 $\mathrm{g} \mathrm{ha}^{-1}$ ) and quinclorac $\left(560 \mathrm{~g} \mathrm{ha}^{-1}\right)$ were applied at the 4- to 6-leaf stage of rice (V4-V6) due to rainfall events that delayed earlier placement of these herbicides. In 2010, application was conducted at 2- leaf stage (V2) using $3364 \mathrm{~g} \mathrm{ha}^{-1}$ of propanil and $560 \mathrm{~g} \mathrm{ha}^{-1}$ of quinclorac. Treatment applications were performed using a boom equipped with three flatfan nozzles (Teejet XR11002, Spraying Systems Co., P.O. Box 7900 , Wheaton, IL 60188) spaced $50 \mathrm{~cm}$ apart. The boom was coupled to a $\mathrm{CO}_{2}$-pressurized backpack sprayer calibrated to deliver $140 \mathrm{~L} \mathrm{ha}^{-1}$ of spray solution at $172 \mathrm{kPa}$. The day before establishment of the season-long flood, maintenance applications were performed in all plots using a tractor sprayer. In 2009, halosulfuron-methyl $\left(67 \mathrm{~g} \mathrm{ha}^{-1}\right)$ plus zetacypermethrin $\left(28 \mathrm{~g} \mathrm{ha}^{-1}\right)$ were used to control sedges and insects, respectively. Only the insecticide zeta-cypermethrin $\left(28 \mathrm{~g} \mathrm{ha}^{-1}\right)$ was sprayed in 2010.

Rice injury was estimated visually using a scale of 0 to $100 \%$, where $0=$ no rice injury and $100=$ rice death. Visual assessments were conducted at 10, 22, 32 and 38 DAE for PRE application of saflufenacil. In 2010, the first evaluation was conducted at 15 DAE instead of 10 DAE. Therefore, data collected at 10 and 15 DAE were used for statistical analysis of combined years. In the experiments with POST treatment of saflufenacil, injury was reported at $3,8,18$ and 24 days after saflufenacil application (DAA) in 2009 and at 6, 12, 19 and 24 DAA in 2010. For statistical analysis of combined years, data were paired according to the assessment order of each year. Therefore, results from 3 and 6 DAA were considered the first evaluation, as well as the data from 8 and 12 DAA were used for the second evaluation. This approach was followed until the last injury rating. Rice heading was determined to be the day in which more than $50 \%$ of the plants had the panicle emerged from the leaf sheath [28]. Rice fields were drained before harvesting at 100 DAE in 2009 and 110 DAE in 2010. Four plot rows were harvested with a mechanical harvester when grain moisture was approximately $20 \%$. Harvested samples were weighed and a moisture meter was used to determine the moisture content of individual samples. Final grain yield was adjusted to $12 \%$ moisture and converted to $\mathrm{kg} \mathrm{ha}^{-1}$. Subsequently, a sub-sample was removed, dried and used to determine milling yield. Dried samples were processed using a ricemilling machine (Zaccaria rice-testing, model PAZ/1-DTA, Indústria Machina Zaccaria S/A, Rua Laranjal, 180, Limeira, São Paulo, Brazil 13484-016).

All data were subjected to analysis of variance (ANOVA) using the PROC MIXED procedure of SAS (SAS 9.2 Software, SAS Institute Inc., 100 SAS Campus Drive, Cary, NC 27513-24140). Crop injury data were subjected to arcsine square-root transformation prior to analysis. Subsequently, homogeneity and normality of variance were verified using Bartlett's and Shapiro-Wilk's Test. Data were combined within years, therefore variances were partitioned into random effects (years, blocks within years and years by treatment interactions) and fixed effects (clomazone rates, saflufenacil rates and their interactions). Results were combined when interaction of years by treatments were not significant. Means for significant effects were separated using Tukey's Test $(P \leq 0.05)$.

\section{Results and Discussion}

\subsection{Rice Injury}

3.1.1. Saflufenacil Applied Preemergence. Saflufenacil rate by clomazone rate by year interaction was demonstrated by ANOVA at the first (10/15 DAE) and second (22 DAE) assessments in the study with PRE applications of saflufenacil (Table 1). Consequently, results were presented for each year separately. In 2009, no interaction between clomazone and saflufenacil rates was observed at 10 and 22 DAE. No injury from PRE application of saflufenacil alone was observed in 2009 (Table 2). Injury increased following rate increments of clomazone, but it did not surpass $11 \%$ for data collected at 10 DAE. Clomazone applied at $392 \mathrm{~g} \mathrm{ha}^{-1}$ can be used as a reference rate since it provided effective weed control while being safe to rice in sandy soils [14]. Injury from clomazone diminished over time with less than $3 \%$ observed at the later evaluation (22 DAE).

In 2010, no clomazone by saflufenacil interaction was detected in the first assessment (15 DAE). A similar trend for clomazone injury was observed in 2010 when compared with the first assessment of 2009, but higher values (up to $31 \%$ ) were reported in the second year. Relatively higher clomazone injury may be related with plants exposure to lower temperatures in the beginning of the growing season due to an earlier planting date in 2010. For saflufenacil rates, greater injury was observed at the highest rate $\left(200 \mathrm{~g} \mathrm{ha}^{-1}\right)$ when compared with the lower rates (25 to $100 \mathrm{~g} \mathrm{ha}^{-1}$ ). However, injury observed at $200 \mathrm{~g} \mathrm{ha}^{-1}$ was not different than the plots untreated with saflufenacil. These results are associated with variability of clomazone when data were averaged across saflufenacil rates.

A significant clomazone and saflufenacil rate interaction occurred for the second evaluation of 2010 (22 DAE). Injury was significantly different for saflufenacil treatments at 100 and $200 \mathrm{~g} \mathrm{ha}^{-1}$, however it was $<6 \%$ (Table 3 ). Necrotic tissue was visible in the lower region of the plant stem when saflufenacil was applied alone. In the treatments with PRE combinations of clomazone and saflufenacil greater injury was observed when the highest rates of the two herbicides were tank-mixed. Injury among saflufenacil rates ranged from 10 to $23 \%$ at $392 \mathrm{~g} \mathrm{ha}^{-1}$ of clomazone and from 20 to 40 at $505 \mathrm{~g} \mathrm{ha}^{-1}$ of clomazone.

At the intermediate rate of clomazone $\left(392 \mathrm{~g} \mathrm{ha}^{-1}\right)$, no differences were detected from 0 up to $100 \mathrm{~g} \mathrm{ha}^{-1}$ of saflufenacil, demonstrating potential for use of these two herbicides. For the highest rate of clomazone, the treatment with no application of saflufenacil had statistically similar injury compared with the highest rate of saflufenacil. Variability within the highest rate of clomazone may explain these 
TABle 1: $P$ values for multiple assessments of visible injury, yield, and whole grain for preemergence (PRE) and postemergence (POST) applications of saflufenacil.

\begin{tabular}{|c|c|c|c|c|c|c|c|}
\hline \multirow{3}{*}{ Experiment } & \multirow{3}{*}{$\begin{array}{l}\text { Source of } \\
\text { variation }\end{array}$} & \multicolumn{6}{|c|}{$\operatorname{Pr}>\mathrm{F}$ for analyzed parameters } \\
\hline & & \multicolumn{4}{|c|}{ Visible injury $^{\mathrm{a}}$} & \multirow{2}{*}{ Yield } & \multirow{2}{*}{ Whole grain } \\
\hline & & 1 st & 2nd & 3rd & 4 th & & \\
\hline \multirow{8}{*}{ PRE } & Year $(\mathrm{Y})$ & $<0.0001$ & $<0.0001$ & $<0.0001$ & $<0.0001$ & $<0.0001$ & $<0.0001$ \\
\hline & Block (year) & $<0.0001$ & 0.040 & 0.072 & 0.979 & 0.701 & 0.771 \\
\hline & Clomazone (C) & $<0.0001$ & $<0.0001$ & $<0.0001$ & 0.007 & 0.025 & 0.772 \\
\hline & $\mathrm{C}^{*} \mathrm{Y}$ & $<0.0001$ & $<0.0001$ & $<0.0001$ & 0.007 & 0.641 & 0.0008 \\
\hline & Saflufenacil (S) & 0.001 & $<0.0001$ & 0.128 & $<0.0001$ & 0.151 & 0.699 \\
\hline & $S^{*} \mathrm{Y}$ & 0.198 & 0.0003 & 0.015 & $<0.0001$ & 0.912 & 0.669 \\
\hline & $\mathrm{C}^{*} \mathrm{~S}$ & 0.495 & 0.163 & 0.458 & 0.109 & 0.450 & 0.971 \\
\hline & $\mathrm{C}^{*} \mathrm{~S} * \mathrm{Y}$ & 0.047 & 0.020 & 0.764 & 0.109 & 0.809 & 0.614 \\
\hline \multirow{8}{*}{ POST } & Year $(\mathrm{Y})$ & $<0.0001$ & $<0.0001$ & $<0.0001$ & $<0.0001$ & $<0.0001$ & $<0.0001$ \\
\hline & Block (year) & 0.016 & 0.193 & $<0.0001$ & 0.0135 & 0.020 & 0.0003 \\
\hline & Clomazone (C) & $<0.0001$ & $<0.0001$ & 0.589 & 0.329 & 0.012 & 0.029 \\
\hline & $\mathrm{C}^{*} \mathrm{Y}$ & 0.017 & 0.026 & 0.589 & 0.329 & 0.050 & 0.029 \\
\hline & Saflufenacil (S) & $<0.0001$ & $<0.0001$ & $<0.0001$ & $<0.0001$ & 0.272 & 0.7475 \\
\hline & $S^{*} \mathrm{Y}$ & $<0.0001$ & $<0.0001$ & $<0.0001$ & $<0.0001$ & 0.659 & 0.804 \\
\hline & $C^{*} S$ & $<0.0001$ & $<0.0001$ & 0.0008 & 0.0037 & 0.634 & 0.274 \\
\hline & $\mathrm{C}^{*} \mathrm{~S}^{*} \mathrm{Y}$ & $<0.0001$ & $<0.0001$ & 0.0008 & 0.0037 & 0.973 & 0.956 \\
\hline
\end{tabular}

${ }^{a}$ Represents the 1st, 2nd, 3rd, and 4th assessment evaluations for visible injury.

TABlE 2: Rice (Oryza sativa L.) visible injury at 10 days after emergence (DAE) and 22 DAE in 2009 and 15 DAE in 2010 in response to saflufenacil and clomazone applied preemergence. Saflufenacil results were averaged across clomazone rates, and clomazone results were averaged across saflufenacil rates.

\begin{tabular}{lccc}
\hline \multirow{2}{*}{$\begin{array}{c}\text { Saflufenacil } \\
\text { rates }\left(\mathrm{g} \mathrm{ha}^{-1}\right)\end{array}$} & \multicolumn{3}{c}{ Visual injury $^{\mathrm{a}}$} \\
& $10 \mathrm{DAE}$ & 2009 & 2010 \\
0 & $5^{\mathrm{b}}$ & $2^{\mathrm{b}}$ & $21 \mathrm{ab}^{\mathrm{c}}$ \\
25 & 4 & 1 & $17 \mathrm{~b}$ \\
50 & 6 & 2 & $16 \mathrm{~b}$ \\
100 & 6 & 2 & $16 \mathrm{~b}$ \\
200 & 9 & 3 & $23 \mathrm{a}$ \\
\hline Clomazone & & & \\
rates $\left(\mathrm{g} \mathrm{ha}^{-1}\right)$ & & $2 \mathrm{ab}$ & $1 \mathrm{c}$ \\
\hline $0^{\mathrm{d}}$ & $0 \mathrm{c}$ & $1 \mathrm{~b}$ & $24 \mathrm{~b}$ \\
392 & $8 \mathrm{~b}$ & $3 \mathrm{a}$ & $31 \mathrm{a}$ \\
505 & $11 \mathrm{a}$ & & \\
\hline
\end{tabular}

${ }^{a}$ Injury was estimated visually using a scale of 0 to $100 \%$ where $0=$ no rice injury and $100=$ rice death. ${ }^{\mathrm{b}}$ Means were not different according to F-test at $P \leq 0.05$. ${ }^{\mathrm{c}}$ Means followed by a different letter are significantly different according to the Tukey's test $(P \leq 0.05)$. ${ }^{\mathrm{d}}$ Plots that did not receive clomazone were treated with propanil plus quinclorac.

results. Clomazone plus saflufenacil applied PRE resulted in typical foliar bleaching followed by necrosis. Additionally, necrosis of the lower region of the stem was caused by the inhibition of the PPO enzyme by saflufenacil (Figure 1(c)).
TABLE 3: Rice (Oryza sativa L.) visible injury at 22 DAE in response to saflufenacil and clomazone applied preemergence. Data represent an interaction between rates of saflufenacil and clomazone in 2010 .

\begin{tabular}{lccc}
\hline $\begin{array}{c}\text { Saflufenacil } \\
\text { rates }\left(\mathrm{g} \mathrm{ha}^{-1}\right)\end{array}$ & \multicolumn{3}{c}{$\begin{array}{c}\text { Visual injury } \\
\text { Clomazone rates }\left(\mathrm{g} \mathrm{ha}^{-1}\right)\end{array}$} \\
\hline & $0^{\mathrm{b}}$ & 392 & 505 \\
0 & $0 \mathrm{c}^{\mathrm{c}}$ & $15 \mathrm{bc}$ & $25 \mathrm{ab}$ \\
25 & $0 \mathrm{c}$ & $15 \mathrm{bc}$ & $20 \mathrm{~b}$ \\
50 & $0 \mathrm{c}$ & $10 \mathrm{c}$ & $20 \mathrm{~b}$ \\
100 & $4 \mathrm{~b}$ & $18 \mathrm{ab}$ & $20 \mathrm{~b}$ \\
200 & $6 \mathrm{a}$ & $23 \mathrm{a}$ & $40 \mathrm{a}$ \\
\hline
\end{tabular}

${ }^{a}$ Injury was estimated visually using a scale of 0 to $100 \%$ where $0=$ no rice injury and $100=$ rice death. ${ }^{b}$ Plots that did not receive clomazone were treated with propanil plus quinclorac. ${ }^{\mathrm{c}}$ Means followed by a different letter within a column are significantly different according to the Tukey's test $(P \leq$ $0.05)$.

Although injury was observed at the highest rates of saflufenacil applied PRE as well as when it was combined with clomazone in 2010, rice plants were able to recover over time. In later evaluations, data averaged across years and clomazone rates demonstrated less than 3\% and 2\% injury at 32 and 38 DAE, respectively (data not shown). Rice was consistently tolerant to PRE applications of saflufenacil alone up to $200 \mathrm{~g} \mathrm{ha}^{-1}$ in both years of study.

Other summer and winter grass crops demonstrated the potential of saflufenacil for PRE applications. Summer crops such as corn tolerated up to $200 \mathrm{~g} \mathrm{ha}^{-1}$ of saflufenacil applied PRE [19]. In proso millet, PRE application of 50 and 


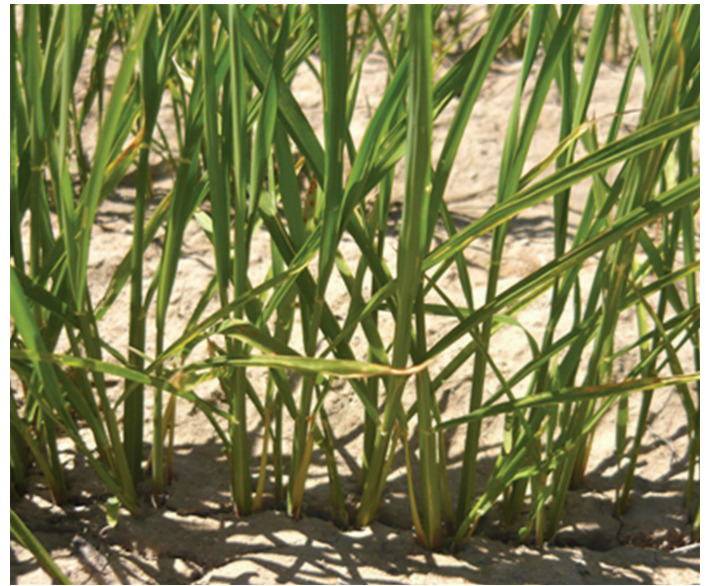

(a)

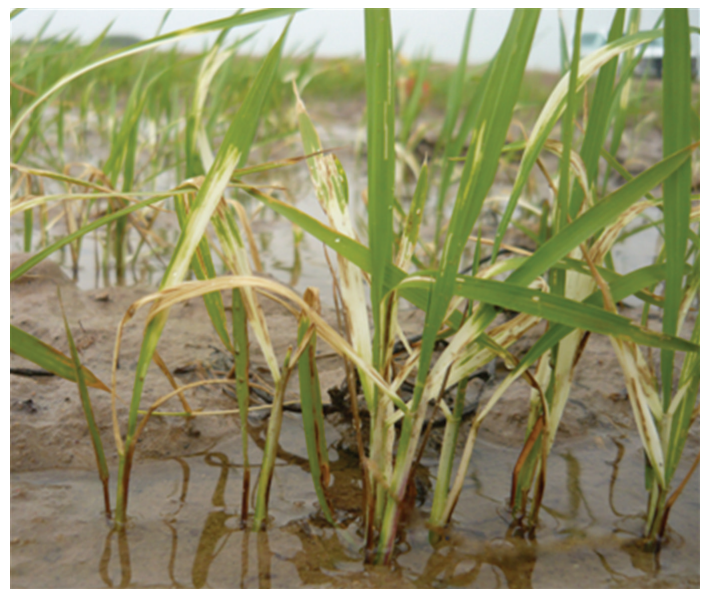

(c)

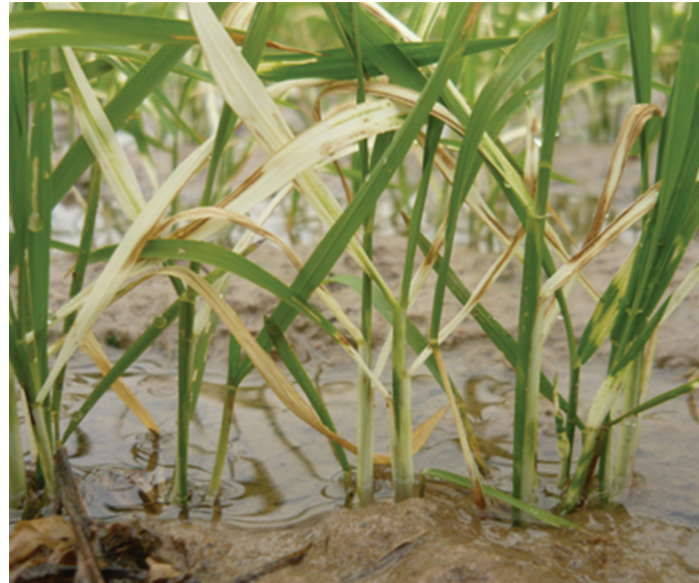

(b)

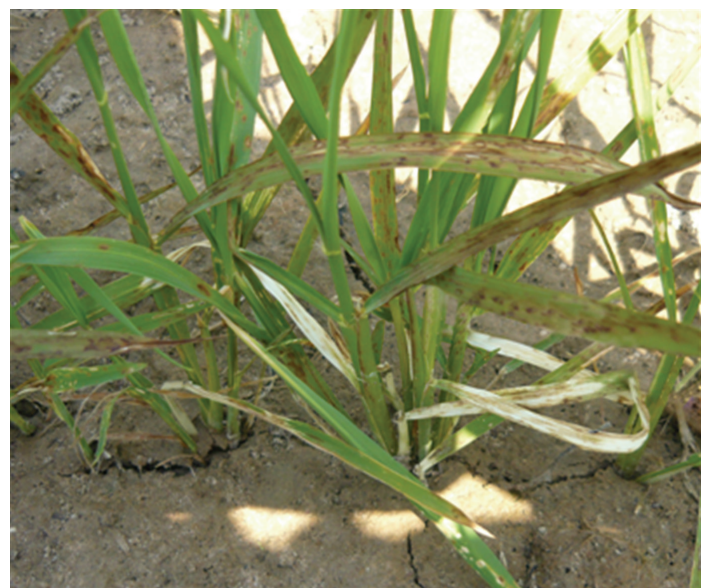

(d)

FIGURE 1: Rice symptoms from clomazone alone (b), clomazone plus saflufenacil applied preemergence (c), and postemergence (d). Untreated check is represented in box (a). Pictures were taken in different rice stages.

$100 \mathrm{~g} \mathrm{ha}^{-1}$ of saflufenacil reduced plant stand comparatively with the untreated check; however, rates did not cause a yield reduction [24]. Winter cereals such as wheat, barley, and oats demonstrated crop tolerance to saflufenacil up to $100 \mathrm{~g} \mathrm{ha}^{-1}$ [18]. In a study conducted by Knezevic et al. [27], saflufenacil rates up to $400 \mathrm{~g} \mathrm{ha}^{-1}$ did not cause injury or yield reduction in winter wheat. In rice, saflufenacil seems to be a potentially useful and safe herbicide for PRE application with clomazone.

3.1.2. Saflufenacil Applied Postemergence. In the study with POST application of saflufenacil, interaction among years, clomazone, and saflufenacil rates was verified by ANOVA for all evaluations, resulting in analysis of data by individual years. In 2009, interaction between rates of saflufenacil and clomazone was observed throughout all assessment timings. Rice injury was observed to be higher with combinations of the highest rate of saflufenacil $\left(50 \mathrm{~g} \mathrm{ha}^{-1}\right)$ and clomazone treatments (Table 4). In evaluations conducted 3 days after POST application (DAA), injury as high as $68 \%$ was observed with the combination of $505 \mathrm{~g} \mathrm{ha}^{-1}$ of clomazone and $50 \mathrm{~g} \mathrm{ha}^{-1}$ of saflufenacil. The mode of action of these herbicides may explain the interaction observed where initial injury from clomazone could deplete the carotenoid pool leading to a more intense action from the radicals produced by inhibition of PPO (saflufenacil). POST application of saflufenacil after spraying clomazone PRE resulted in necrosis on the upper leaves of the rice plants by action of saflufenacil. At the same time, lower leaves were still displaying bleaching symptoms from clomazone (Figure $1(\mathrm{~d})$ ).

Rice injury intensified with increasing rates of saflufenacil alone, reaching up to $18 \%$ in the initial rating of 2009. Application of propanil $\left(4485 \mathrm{~g} \mathrm{ha}^{-1}\right)$ and quinclorac $\left(560 \mathrm{gha}^{-1}\right)$ to control grass weeds in plots that did not receive clomazone caused 5\% injury even in the treatment without saflufenacil POST application. Combinations of the intermediate rate of clomazone $\left(392 \mathrm{~g} \mathrm{ha}^{-1}\right)$ and rates of saflufenacil up to $25 \mathrm{~g} \mathrm{ha}^{-1}$ applied POST resulted in 25\% injury. The initial injury observed from POST application of saflufenacil alone or following a PRE application of clomazone could be acceptable as long as rice plants recover, and rice yield would be not negatively affected by early phytotoxicity. 
TABLE 4: Visible rice (Oryza sativa L.) injury at 3, 8, 18, and 24 days after application (DAA) in response to postemergence application (4to 6-leaf stage, V4-V6) of saflufenacil following preemergence application of clomazone. Data represents an interaction between rates of saflufenacil and clomazone for experiment conducted in 2009.

\begin{tabular}{|c|c|c|c|c|c|c|c|c|c|c|c|c|}
\hline \multirow{4}{*}{$\begin{array}{l}\text { Saflufe- } \\
\text { nacil rates } \\
\left(\mathrm{g} \mathrm{ha}^{-1}\right)\end{array}$} & \multicolumn{12}{|c|}{ Visual injury ${ }^{a}$} \\
\hline & \multirow{2}{*}{\multicolumn{3}{|c|}{$\begin{array}{c}3 \text { DAA } \\
\text { Clomazone rates }\left(\mathrm{g} \mathrm{ha}^{-1}\right)\end{array}$}} & \multirow{2}{*}{\multicolumn{3}{|c|}{$\begin{array}{c}8 \text { DAA } \\
\text { Clomazone rates }\left(\mathrm{g} \mathrm{ha}^{-1}\right)\end{array}$}} & \multirow{2}{*}{\multicolumn{3}{|c|}{$\begin{array}{c}18 \text { DAA } \\
\text { Clomazone rates }\left(\mathrm{g} \mathrm{ha}^{-1}\right)\end{array}$}} & \multirow{2}{*}{\multicolumn{3}{|c|}{$\begin{array}{c}24 \text { DAA } \\
\text { Clomazone rates }\left(\mathrm{g} \mathrm{ha}^{-1}\right)\end{array}$}} \\
\hline & & & & & & & & & & & & \\
\hline & $0^{\mathrm{b}}$ & 392 & 505 & 0 & 392 & 505 & 0 & 392 & 505 & 0 & 392 & 505 \\
\hline & \multicolumn{12}{|c|}{$\%$} \\
\hline 0 & $5 b^{c}$ & $1 \mathrm{~d}$ & $3 \mathrm{~d}$ & $4 \mathrm{~b}$ & $0 \mathrm{c}$ & $1 \mathrm{~d}$ & $0^{\mathrm{d}}$ & $0 \mathrm{~b}$ & $0 \mathrm{~b}$ & $0^{\mathrm{d}}$ & $0 \mathrm{~b}$ & $0 \mathrm{c}$ \\
\hline 12.5 & $11 \mathrm{ab}$ & $11 \mathrm{c}$ & $13 c$ & $10 \mathrm{ab}$ & $6 \mathrm{~b}$ & $8 \mathrm{c}$ & 0 & $0 \mathrm{~b}$ & $0 \mathrm{~b}$ & 0 & $1 \mathrm{~b}$ & $0 \mathrm{c}$ \\
\hline 18.75 & $13 \mathrm{ab}$ & $25 \mathrm{~b}$ & $16 \mathrm{c}$ & $8 \mathrm{ab}$ & $15 \mathrm{~b}$ & $11 \mathrm{c}$ & 6 & $3 \mathrm{~b}$ & $0 \mathrm{~b}$ & 4 & $5 \mathrm{a}$ & $1 \mathrm{bc}$ \\
\hline 25 & $13 \mathrm{ab}$ & $24 \mathrm{bc}$ & $35 \mathrm{~b}$ & $10 \mathrm{ab}$ & $15 \mathrm{~b}$ & $25 \mathrm{~b}$ & 6 & $3 \mathrm{~b}$ & $4 \mathrm{a}$ & 4 & $1 \mathrm{~b}$ & $5 \mathrm{ab}$ \\
\hline 50 & $18 \mathrm{a}$ & $50 \mathrm{a}$ & $68 \mathrm{a}$ & $15 \mathrm{a}$ & $43 \mathrm{a}$ & $46 \mathrm{a}$ & 4 & $14 \mathrm{a}$ & $11 \mathrm{a}$ & 3 & $9 \mathrm{a}$ & $8 \mathrm{a}$ \\
\hline
\end{tabular}

${ }^{a}$ Injury was estimated visually using a scale of 0 to $100 \%$ where $0=$ no rice injury and $100=$ rice death. ${ }^{b}$ Plots that did not receive clomazone were treated with propanil plus quinclorac. ' Means followed by a different letter within a column are significantly different according to the Tukey's test $(P \leq 0.05)$. ${ }^{\mathrm{d}}$ Means were not different according to F-test at $P \leq 0.05$.

In evaluations conducted at $8 \mathrm{DAA}$, rice response to herbicide treatments followed a similar trend as initial evaluation, but overall intensity of injury had already diminished over a 5-day interval. In subsequent evaluations, rice injury decreased significantly to $<14 \%$ and $<9 \%$ for all treatments during assessments performed 2 and 3 weeks after initial evaluation. No significant differences were observed among saflufenacil treatments alone at later ratings. In 2009, nitrogen application and season-long flood were introduced in the experimental area at 10 DAA. These management practices likely helped the injured rice overcome herbicide symptoms more rapidly.

No interaction between clomazone and saflufenacil was verified in 2010. In the evaluation at 6 DAA, injury from saflufenacil averaged across clomazone rates was as high as $26 \%$ at $50 \mathrm{~g} \mathrm{ha}^{-1}$ of saflufenacil, but $<13 \%$ in the remaining saflufenacil treatments (Table 5). In the subsequent evaluation conducted at $12 \mathrm{DAA}$, significantly greater injury was detected at the highest rate of saflufenacil (9\%). However, no differences were observed from 0 to $25 \mathrm{~g} \mathrm{ha}^{-1}$ of saflufenacil. Injury was absent in all plots for evaluations conducted at 19 and 24 DAA.

POST application of saflufenacil is not currently recommended in row crops. Work by others demonstrated injury as high as $76 \%$ in winter cereals from POST application of saflufenacil remaining as high as 35\% almost one month after treatment [18]. Corn demonstrated acceptable tolerance to saflufenacil applied without adjuvant at spike and 2- to 3- leaf stages; however, addition of adjuvant increased injury and caused yield loss, especially when applications were made at the 2- to 3-leaf stage [19]. More recently, results obtained in winter wheat indicated lower injury from POST applications of saflufenacil in combination with 2,4-D amine without nonionic surfactant when compared with saflufenacil alone [25]. In this study, injury occurred with POST application of saflufenacil alone or in a weed control program with clomazone in light-textured soils, but rice plants seemed to recover from early phytotoxicity.

Saflufenacil applications made prior to and after emergence did not affect heading in either year. Therefore, rice
TABle 5: Rice (Orza sativa L.) visible injury at 6 and 12 days after application (DAA) in response to postemergence application (4- to 6-leaf stage, V4-V6) of saflufenacil following preemergence application of clomazone. Saflufenacil results were averaged across clomazone rates, and clomazone results were averaged across saflufenacil rates.

\begin{tabular}{lcc}
\hline $\begin{array}{l}\text { Saflufenacil rates } \\
\left(\mathrm{g} \mathrm{ha}^{-1}\right)\end{array}$ & \multicolumn{2}{c}{$\begin{array}{c}\text { Visual injury } \\
\text { a }\end{array}$} \\
\hline & 6 DAA & 12 DAA \\
\hline 0 & $3 \mathrm{~d}^{\mathrm{b}}$ & $0 \mathrm{~b}$ \\
12.5 & $6 \mathrm{c}$ & $0 \mathrm{~b}$ \\
18.75 & $9 \mathrm{bc}$ & $1 \mathrm{~b}$ \\
25 & $13 \mathrm{~b}$ & $2 \mathrm{~b}$ \\
50 & $26 \mathrm{a}$ & $9 \mathrm{a}$ \\
\hline Clomazone rates & & \\
$\left(\mathrm{g} \mathrm{ha}^{-1}\right)$ & & $2^{\mathrm{d}}$ \\
\hline $0^{\mathrm{c}}$ & $9 \mathrm{~b}$ & 2 \\
392 & $9 \mathrm{~b}$ & 3 \\
505 & $17 \mathrm{a}$ & \\
\hline
\end{tabular}

${ }^{a}$ Injury was estimated visually using a scale of 0 to $100 \%$ where $0=$ no rice injury and $100=$ rice death. ${ }^{\mathrm{b}}$ Means followed by a different letter are significantly different according to the Tukey's test $(P \leq 0.05)$. ${ }^{\text {CPlots that }}$ did not receive clomazone were treated with propanil plus quinclorac. ${ }^{\mathrm{d}}$ Means were not different according to F-test at $P \leq 0.05$.

development was not affected by crop injury observed early in the season from saflufenacil and clomazone treatments. Fifty percent heading was observed at 75 and 82 DAE in 2009 and 2010, respectively. This is in the normal range for a very early maturity cultivar such as "Cocodrie" [29].

3.2. Grain Yield and Quality. No interaction among herbicide treatments and years was revealed by ANOVA; therefore, results were combined over years. Also, no interaction among clomazone and saflufenacil was detected from pooled data during the 2-year study. Consequently, grain yield was presented according to saflufenacil rates. Rice yield was 


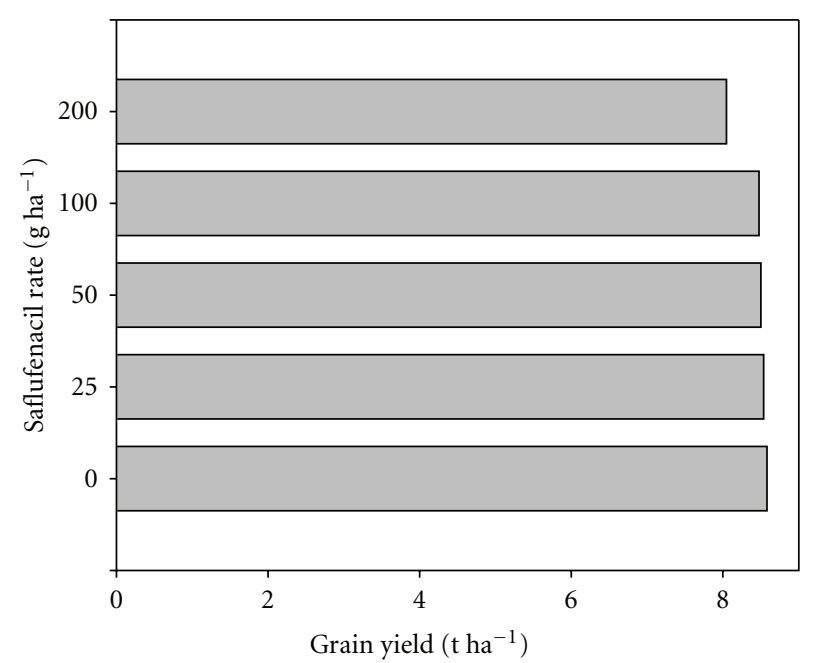

(a)

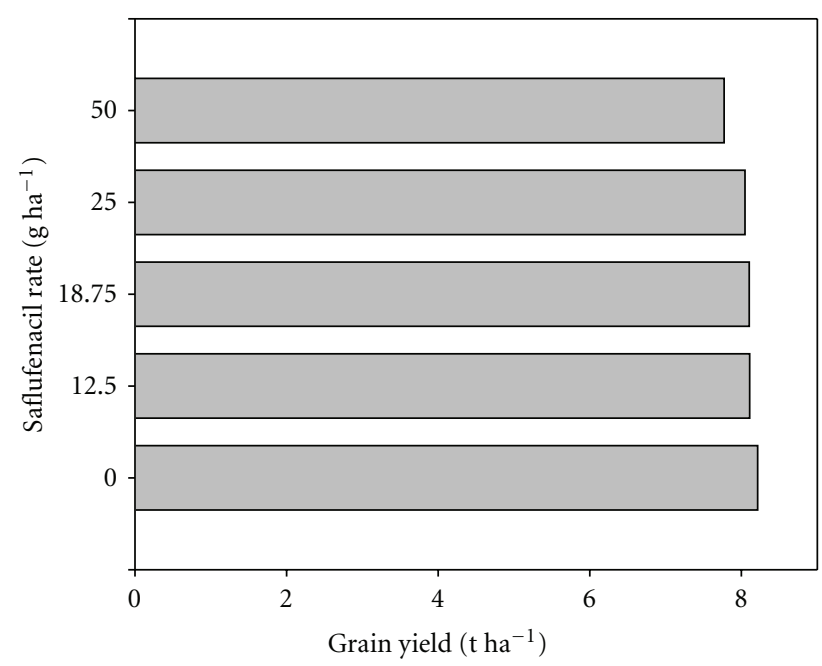

(b)

FIGURE 2: Grain yield $\left(\mathrm{tha}^{-1}\right)$ in response to preemergence (a) and postemergence (b) application of saflufenacil following preemergence application of clomazone. Data were averaged across clomazone rates. Means were not different according to F-test at $P \leq 0.05$.

not significantly affected by saflufenacil PRE and POST applications (Figure 2). Grain yield ranged from 8.05 to $8.58 \mathrm{t} \mathrm{ha}^{-1}$ among the PRE rates of saflufenacil. For the POST rates of saflufenacil, rice yield was between 7.78 to $8.21 \mathrm{tha}^{-1}$.

Although injury of almost 70\% occurred early in the season from combinations of clomazone PRE and saflufenacil POST applications, rice yield was not adversely affected in any saflufenacil treatment. Contradictory, injury from POST application of saflufenacil in corn [19], barley, oats, and wheat [18] and winter wheat [27] significantly reduced yield. Differences in intrinsic tolerance and crop management associated with rice production such as nitrogen fertilization followed by establishment of flooding may be favoring rice recovery from clomazone and saflufenacil injury.

Whole grain percentage was similar among saflufenacil rates in PRE and POST application studies. Whole grain yield was higher than $60 \%$ for all rates of saflufenacil applied PRE and POST in the average of two years of data (data not shown). This would be an expected result considering that no delay in heading was reported from herbicides treatments.

In summary, rice was consistently tolerant to PRE applications of saflufenacil alone up to $200 \mathrm{~g} \mathrm{ha}^{-1}$ in both years of study. Combination of saflufenacil up to $100 \mathrm{~g} \mathrm{ha}^{-1}$ with an intermediate rate of clomazone $\left(392 \mathrm{~g} \mathrm{ha}^{-1}\right)$ can be a potential mixture for PRE application in rice regarding crop tolerance. Greater injury occurred when saflufenacil was applied POST at $50 \mathrm{~g} \mathrm{ha}^{-1}$ following clomazone. However, saflufenacil rates up to $25 \mathrm{~g} \mathrm{ha}^{-1}$ applied POST following an intermediate rate of clomazone resulted in initial rice injury that rapidly diminished. Rice yield was not adversely affected by saflufenacil rates applied either PRE or POST in a clomazone weed control program in light-textured soils.

\section{Acknowledgments}

The authors thank the $\mathrm{CNPq}$, Conselho Nacional de Desenvolvimento Científico e Tecnológico, Brazil, for the student scholarship and BASF Corporation for funding the research.
They would like to acknowledge John Harden, Steve Bowe, Tom Holt, and Rex Liebl for their valuable contributions during the organization of the studies and for the opportunity to work with the chemical, and Benjamin McKnight, Aaron Turner, Jack Vawter, and Jason Samford for their assistance during the conduction of the experiments.

\section{References}

[1] D. Kennedy, "The importance of rice," Science, vol. 296, no. 5565, p. 13, 2002.

[2] B. Lin, Z. Tan, G. Xiao et al., "Evaluation of compositional and nutritional equivalence of genetically modified rice to conventional rice using in situ and in vitro techniques," Journal of the Science of Food and Agriculture, vol. 89, no. 9, pp. 14901497, 2009.

[3] M. Walter, E. Marchezan, and L. A. De Avila, "Rice: composition and nutritional characteristics," Ciencia Rural, vol. 38, no. 4, pp. 1184-1192, 2008.

[4] FAO, Food and Agriculture Organization of United Nations, "Statistics, FAOSTAT-Agriculture, Production, Crops," 2011, http://faostat.fao.org/site/567/default.aspx\#ancor.

[5] M. Aureus and L. Reyes, "Rice for future generations," Rice Today, pp. 12-15, 2011.

[6] USDA, United States Department of Agriculture, "Producers, Data and Statistics, Reports by Commodity," 2011, http://www .nass.usda.gov/Statistics_by_Subject/index.php.

[7] K. Saito, "Weed pressure level and the correlation between weed competitiveness and rice yield without weed competition: an analysis of empirical data," Field Crops Research, vol. 117, no. 1, pp. 1-8, 2010.

[8] T. Webster, "Weed survey-southern states," Proceedings Southern Weed Science Society, vol. 53, pp. 247-274, 2000.

[9] J. K. Norsworthy, N. R. Burgos, R. C. Scott, and K. L. Smith, "Consultant perspectives on weed management needs in Arkansas rice," Weed Technology, vol. 21, no. 3, pp. 832-839, 2007.

[10] H. R. Mitchell and E. V. Gage, "Command 3 ME: weed control in southern rice," Proceedings Southern Weed Science Society, vol. 52, p. 186, 1999. 
[11] R. E. Talbert and N. R. Burgos, "History and management of herbicide-resistant barnyardgrass (Echinochloa crus-galli) in Arkansas rice," Weed Technology, vol. 21, no. 2, pp. 324-331, 2007.

[12] S. A. Senseman, Herbicide Handbook, Weed Science Society of America, Lawrence, Kan, USA, 9th edition, 2007.

[13] E. F. Scherder, R. E. Talbert, and S. D. Clark, "Rice (Oryza sativa) cultivar tolerance to clomazone," Weed Technology, vol. 18, no. 1, pp. 140-144, 2004.

[14] S. D. Willingham, N. R. Falkenberg, G. N. McCauley, and J. M. Chandler, "Early postemergence clomazone tank mixes on coarse-textured soils in rice," Weed Technology, vol. 22, no. 4, pp. 565-570, 2008.

[15] E. P. Webster, F. L. Baldwin, and T. L. Dillon, "The potential for clomazone use in rice (Oryza sativa)," Weed Technology, vol. 13, no. 2, pp. 390-393, 1999.

[16] A. M. Baltazar and R. J. Smith Jnr, "Propanil-resistant barnyardgrass (Echinochloa crus-galli) control in rice (Oryza sativa)," Weed Technology, vol. 8, no. 3, pp. 576-581, 1994.

[17] M. S. Malik, N. R. Burgos, and R. E. Talbert, "Confirmation and control of propanil-resistant and quinclorac-resistant barnyardgrass (Echinochloa crus-galli) in rice," Weed Technology, vol. 24, no. 3, pp. 226-233, 2010.

[18] P. H. Sikkema, C. Shropshire, and N. Soltani, "Tolerance of spring barley (Hordeum vulgare L.), oats (Avena sativa L.) and wheat (Triticum aestivum L.) to saflufenacil," Crop Protection, vol. 27, no. 12, pp. 1495-1497, 2008.

[19] N. Soltani, C. Shropshire, and P. H. Sikkema, "Response of corn to preemergence and postemergence applications of saflufenacil," Weed Technology, vol. 23, no. 3, pp. 331-334, 2009.

[20] N. Soltani, C. Shropshire, and P. H. Sikkema, "Sensitivity of leguminous crops to saflufenacil," Weed Technology, vol. 24, no. 2, pp. 143-146, 2010.

[21] P. W. Geier, P. W. Stahlman, and L. D. Charvat, "Dose responses of five broadleaf weeds to saflufenacil," Weed Technology, vol. 23, no. 2, pp. 313-316, 2009.

[22] R. A. Liebl, H. Walter, S. J. Bowe, T. J. Holt, and D. E. Westberg, "BAS $800 \mathrm{H}$ : a new herbicide for preplant burndown and preemergence dicot weed control," Proceedings Weed Science Society of America, vol. 48, p. 120, 2008.

[23] K. Grossmann, R. Niggeweg, N. Christiansen, R. Looser, and T. Ehrhardt, "The herbicide saflufenacil (Kixor) is a new inhibitor of protoporphyrinogen IX oxidase activity," Weed Science, vol. 58, no. 1, pp. 1-9, 2010.

[24] D. J. Lyon and A. R. Kniss, "Proso millet tolerance to saflufenacil," Weed Technology, vol. 24, no. 3, pp. 349-355, 2010.

[25] J. C. Frihauf, P. W. Stahlman, and P. W. Geier, "Winter wheat and weed response to postemergence saflufenacil alone and in mixtures," Weed Technology, vol. 24, no. 3, pp. 262-268, 2010.

[26] J. C. Frihauf, P. W. Stahlman, P. W. Geier, and D. E. Peterson, "Winter annual broadleaf weeds and winter wheat response to postemergence application of two saflufenacil formulations," Weed Technology, vol. 24, no. 4, pp. 416-424, 2010.

[27] S. Z. Knezevic, A. Datta, J. Scott, and L. D. Charvat, "Tolerance of winter wheat (Triticum aestivum L.) to pre-emergence and post-emergence application of saflufenacil," Crop Protection, vol. 29, no. 2, pp. 148-152, 2010.

[28] P. A. Counce, T. C. Keisling, and A. J. Mitchell, "A uniform, objectives, and adaptive system for expressing rice development," Crop Science, vol. 40, no. 2, pp. 436-443, 2000.

[29] M. O. Way, Texas Rice Production Guidelines, Texas AgriLife Research, Texas AgriLife Extension, and United States Department of Agriculture, Beaumont, Tex, USA, 2010. 


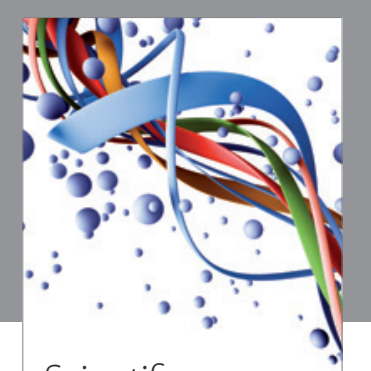

Scientifica
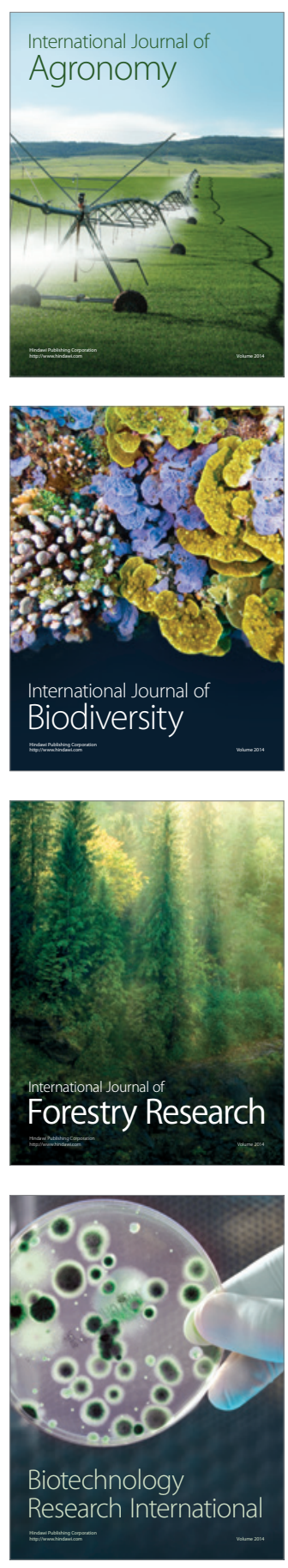
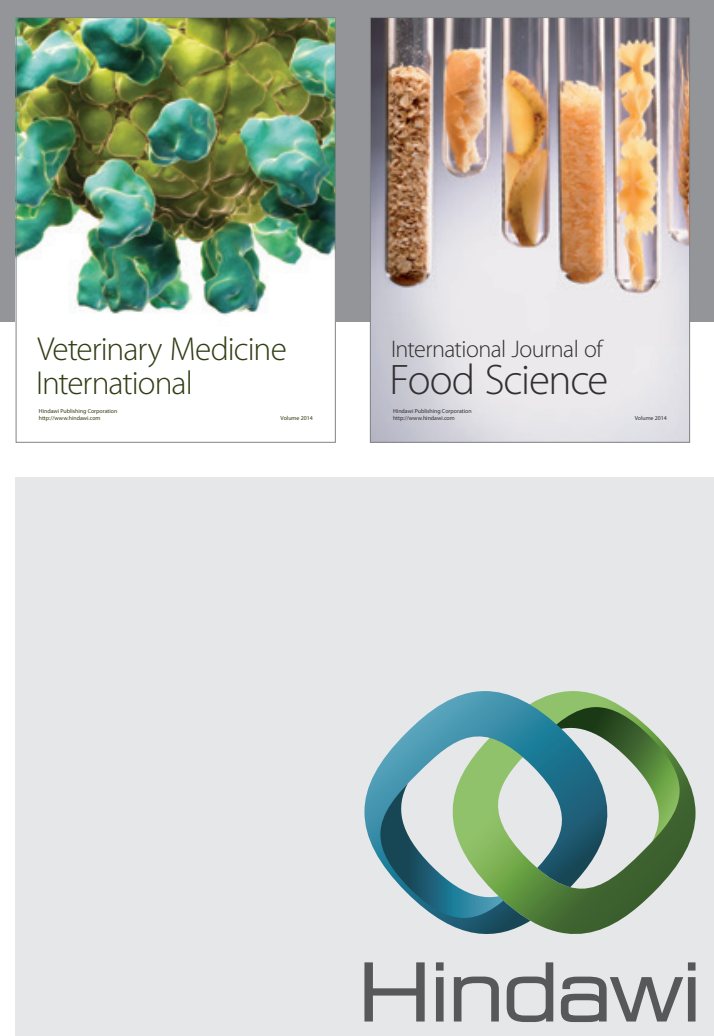

Submit your manuscripts at

http://www.hindawi.com
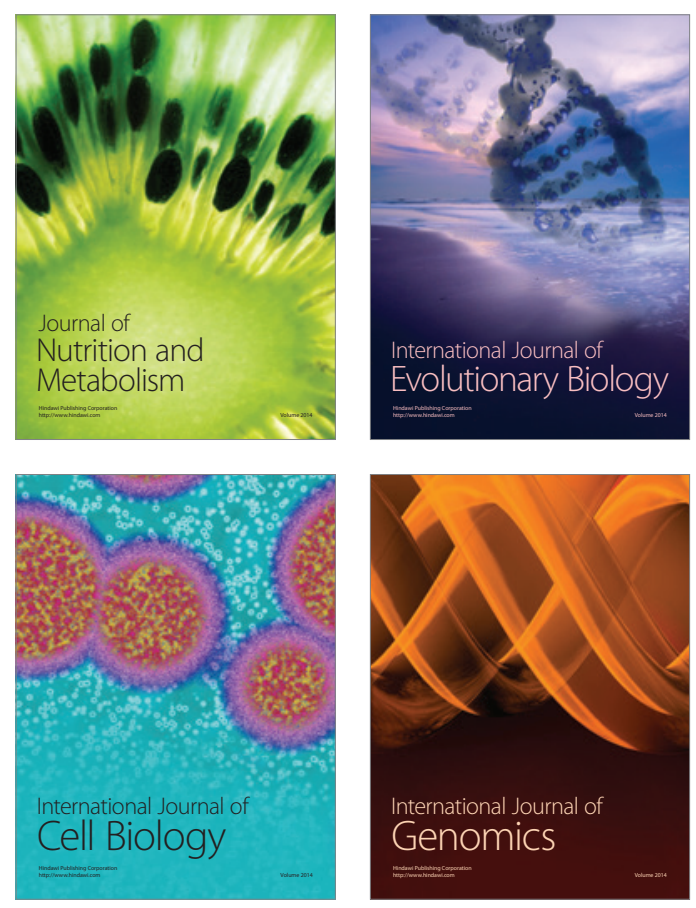
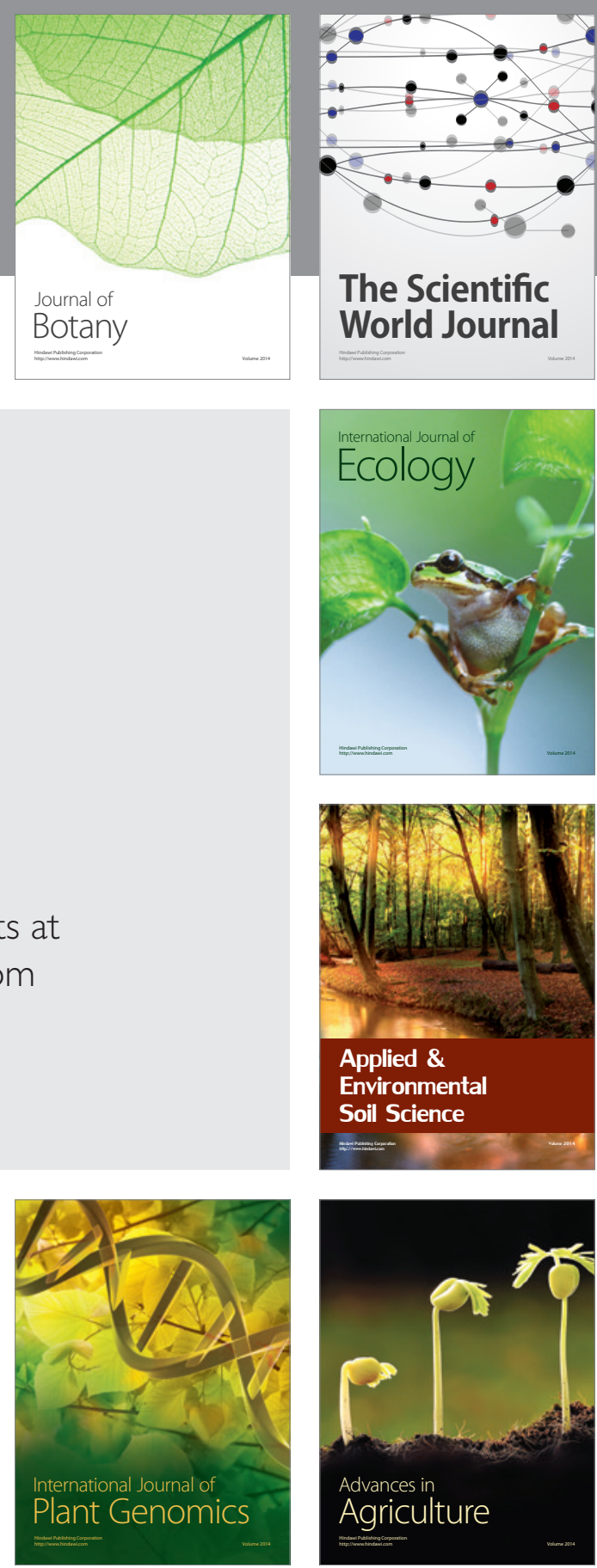

The Scientific World Journal
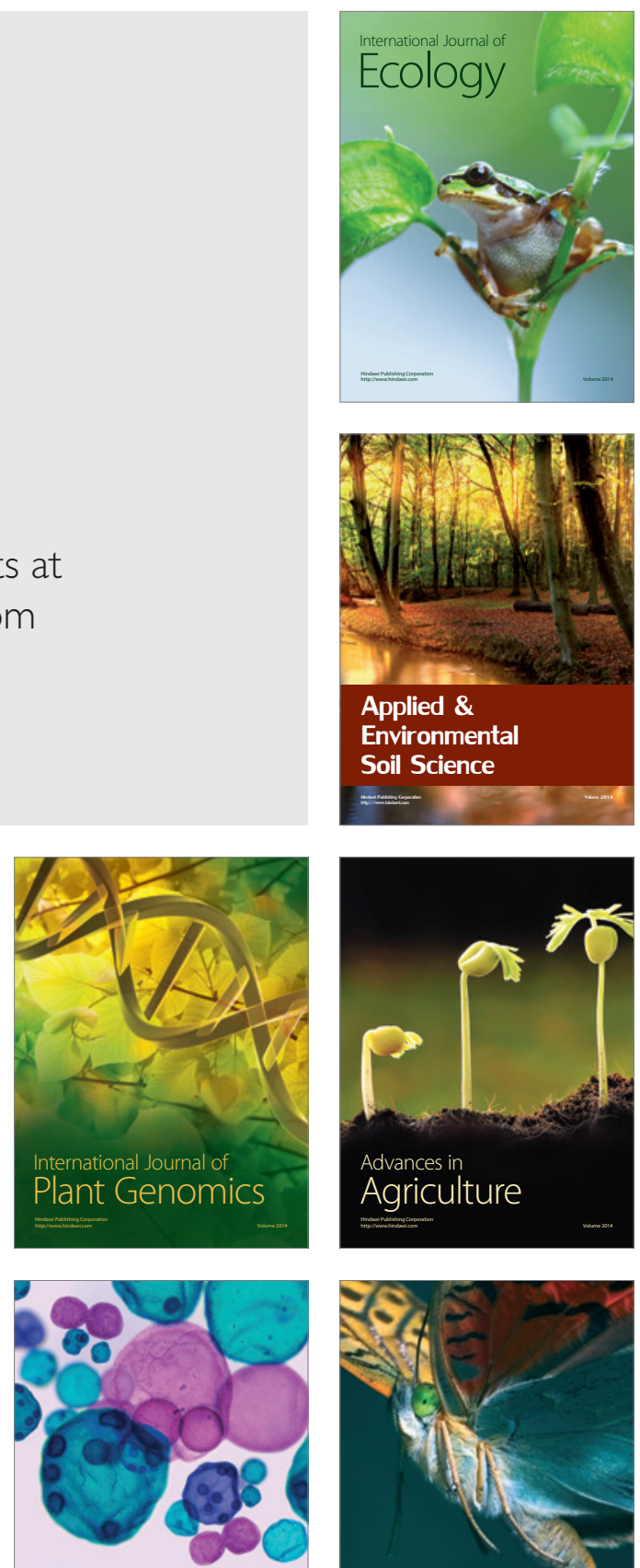

International Journal of Microbiology

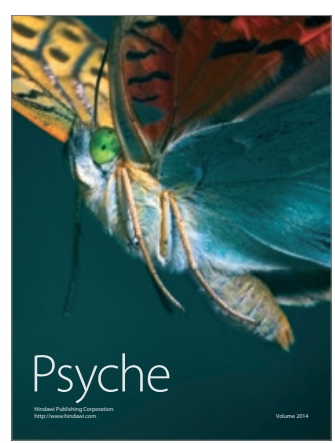

